УДК 636.22/.28:612.59(477.65)

(C) 2013

Гончарова I. І., кандидат сільськогосподарських наук

Харківська державна зооветеринарна академія

\title{
ВІДТВОРНІ ТА ФІЗІОЛОГІЧНІ ПОКАЗНИКИ ТЕЛИЦЬ М'ЯСНИХ ПОРІД В УМОВАХ СТЕПОВОЇ ЗОНИ УКРАЇНИ
}

\section{Рецензент - доктор сільськогосподарських наук, професор Ю. Д. Рубан}

\begin{abstract}
Викладено результати живої маси і відтворювальної здатності телиць знам'янського внутрішньопородного типу поліської м'ясної породи з різним рівнем годівлі. Встановлена оптимальна жива маса і вік плідного парування телищь. Так, інтенсивне вирощування телиць забезпечує середньодобовий приріст 700-800 г, живу масу 385 кг у 1516-місячному віщі. Крім того наведено результати досліджень адаптації телищь у пасовищний період. Експериментально обтрунтовано, що абсолютні показники, які характеризують ступінь адаптаційної пластичності тварин иүієї породи, свідчать про дочільність ї̈ розведення у степовій зоні Украӥни.
\end{abstract}

Ключові слова: жива маса, відтворювальна здатність, рівень годівлі, адаптація, толерантність, термостійкість, індекс теплостійкості.

Постановка проблеми. Україна характеризується різноманітністю щодо зон i природнокліматичних умов, які необхідно враховувати в районуванні, створенні нових порід і типів м'ясної худоби. Зарубіжний досвід (США, Канада, Франція та ін.) свідчить, що для кожної зони (i навіть мікрозони) необхідно мати не менше 2-3-х добре поєднаних між собою м'ясних порід 3 іншими молочними та молочно-м'ясними породами для отримання помісей і гібридів із високим генетичним потенціалом продуктивності, які б забезпечували ефект гетерозису [1-4].

Аналіз основних досліджень і публікацій, у яких започатковано розв'язання проблеми. В умовах України висока ефективність галузі досягається лише у випадку інтенсивного ведення м'ясного скотарства й розведення великих м'ясних порід. Значний імпорт недоцільний через витрати чималої кількості валютних коштів, підвищених вимог до умов годівлі та утримання поголів'я. Виходячи 3 цього, українські вчені розробили програми створення власних вітчизняних порід із високою м'ясною продуктивністю та пристосованістю до місцевих природнокліматичних умов. Першим результатом цієї роботи стало створення й утвердження української, волинської м'ясних порід.
Водночас у східному регіоні країни велося формування знам'янського внутрішньопородного типу поліської породи шляхом складного відтворного схрещування тварин червоної степової та симентальської порід (материнський тип) iз абердин-ангуськими та шаролезькими плідниками (батьківський тип).

Особливий інтерес представляють ріст і розвиток тварин, відтворювальна здатність, біохімічні зміни крові, акліматизаційні здібності тварин до різних природно-кліматичних зон. У тварин, недостатньо адаптованих до нових умов, знижується резистентність, порушується відтворна здатність, затримується ріст і збільшуються витрати кормів [1, 2, 4].

Метою досліджень $\epsilon$ вивчення відтворювальних здібностей телиць знам'янського внутрішньопородного типу поліської м'ясної породи та можливості їі використання в даній кліматичній зоні.

Завдання досліджень - провести порівняльне вивчення впливу віку i живої маси на рівень запліднення телиць, які знаходяться на різному вирощуванні, а також їх акліматизаційні здібності.

Матеріал і методи досліджень. Дослідні телиці від відлучення і до парувального віку знаходилися за різної інтенсивності вирощування. Так, телиці I контрольної групи, згідно з нормами ВІЖ, мали рівень годівлі (РГ) - 1,57; II - низький $(1,46)$; III - високий $(1,75)$; IV - помірноінтенсивний $(1,64)$.

Зважування телиць проводили щомісяця протягом усього досліду перед годівлею. На підставі цього визначалися жива маса тварин і розрахунок середньодобових приростів.

Відтворювальну здатність оцінювали за показником плідного запліднення.

У дослідах вивчали вплив віку і живої маси на рівень запліднення телиць.

Біохімічні показники: загальний білок рефрактометричним, а співвідношення білкових фракцій - за допомогою електрофорезу на папері.

Адаптацію тварин до умов зовнішнього середовища визначали влітку (липень) вранці та вве- 
чері (на трьох головах із кожної групи). На основі виміру температури тіла (ректально), частоти пульсу шляхом пальпування хвостової артерії і дихання (за рухом черевних м'язів).

На основі цих даних розраховували за формулами коефіцієнт адаптації, коефіцієнт толерантності - індекс теплостійкості та коефіцієнт термостійкості (за загальноприйнятою формулою).

Результати досліджень. Дослідження показали, що телиці з різним рівнем годівлі мали неоднакову живу масу при плідному паруванні, середньодобові прирости та відтворювальні здібності (табл. 1).

Так, телиці III і IV дослідних груп на 4-5 місяців були молодшими, ніж I контрольна, і на 78 місяців, ніж II дослідна група на час плідного парування, що свідчить про вищу скоростиглість інтенсивно вирощених телиць.

Між телицями, вирощеними за умови різної інтенсивності, спостерігаються деякі відмінності за показниками відтворювальної здатності.

Жива маса телиць на час плідного парування була практично однакова, але телиці III і IV груп за умови більш інтенсивного вирощування досягли iii раніше. I, відповідно, від них значно раніше був одержаний приплід.

Так, телиці I контрольної групи досягли такої живої маси у 20 місяців і були запліднені. Парування телиць II групи було здійснено у віці 23 місяці з живою масою 382,0 кг.

Найвищою заплідненістю від першого парування характеризувалися телиці III та IV груп у порівнянні з контрольною на 6 і 2,9%. Незважаючи на те, що парування телиць проводили в ранньому віці, у них однак спостерігалося по 2-3 статевих цикли.

Після 12-місячного віку у телиць пропускали одну-дві охоти і у віці 15-16 місяців їх парували.

\section{1. Показники живої маси та відтворювальна здатність телиць при плідному паруванні}

$$
(\bar{X} \pm s \bar{x})
$$

\begin{tabular}{|c|c|c|c|c|}
\hline \multirow{2}{*}{ Показник } & \multicolumn{4}{|c|}{ Група } \\
\cline { 2 - 5 } & I (РГ 1,57) & II (РГ 1,46) & III (РГ 1,75) & IV (РГ 1,64) \\
\hline Парування, діб: плідне & $606,0 \pm 4,9$ & $690,0 \pm 4,56$ & $460,0 \pm 4,35$ & $480,0 \pm 4,02$ \\
\hline $\begin{array}{c}\text { Жива маса, кг: } \\
\text { за плідного парування }\end{array}$ & $384,0 \pm 6,29$ & $382,0 \pm 7,72$ & $386,0 \pm 3,21$ & $385,3 \pm 4,05$ \\
\hline $\begin{array}{c}\text { Середньдобовий приріст } \\
\text { від народження } \\
\text { до парування, г }\end{array}$ & $583,0 \pm 9,78$ & $503,0 \pm 11,01 * * *$ & $780,0 \pm 6,82 * * *$ & $731,0 \pm 8,63 * * *$ \\
\hline $\begin{array}{c}\text { Заплідненість від першого } \\
\text { парування, \% }\end{array}$ & 70,0 & 66,0 & 76,0 & 72,9 \\
\hline $\begin{array}{c}\text { Кількість осіменінь } \\
\text { для запліднення }\end{array}$ & 2,0 & 2,2 & 1,5 & 1,8 \\
\hline $\begin{array}{c}\text { Жива маса на час } \\
\text { отелення, кг }\end{array}$ & $465,8 \pm 6,26$ & $445,8 \pm 7,56^{*}$ & $489,1 \pm 6,29 *$ & $470,4 \pm 6,35$ \\
\hline
\end{tabular}

Примітка: 1. Вірогідність різниці стосовно I групи * $\mathrm{P} \geq 0,95$; ** $\mathrm{P} \geq 0,99 ; * * * \mathrm{P} \geq 0,999$.

2. Плідне парування: I група - 20 міс., II - 23 міс., III - 15 міс., IV - 16 міс.

2. Біохімічні показники плазми крові за сезонами року $(\bar{X} \pm S \bar{X}), n=3$

\begin{tabular}{|c|c|c|c|c|}
\hline Група & Білок, г/л & Альбуміни, г/л & Глобуліни, г/л & Коефіцієнт А/Г \\
\hline \multicolumn{5}{|c|}{ ЛІТО (8 місяців) } \\
\hline I & $64,9 \pm 0,25$ & $29,1 \pm 0,10$ & $38,5 \pm 0,46$ & 0,81 \\
\hline II & $63,3 \pm 0,07$ & $28,3 \pm 0,18$ & $35,0 \pm 0,35$ & 0,80 \\
\hline III & $67,5 \pm 0,21$ & $30,8 \pm 0,24$ & $36,7 \pm 0,32$ & 0,84 \\
\hline IV & $65,5 \pm 0,35$ & $29,8 \pm 0,49$ & $36,0 \pm 0,37$ & 0,82 \\
\hline \multicolumn{5}{|c|}{ 3ИМA (15 місяців) } \\
\hline I & $78,0 \pm 0,14$ & $36,5 \pm 1,06$ & $41,5 \pm 0,35$ & 0,88 \\
\hline II & $74,7 \pm 0,49$ & $34,5 \pm 0,45$ & $40,2 \pm 0,28$ & 0,85 \\
\hline III & $82,9 \pm 0,34$ & $39,7 \pm 0,17$ & $43,2 \pm 0,47$ & 0,92 \\
\hline IV & $80,4 \pm 0,63$ & $38,3 \pm 0,41$ & $42,1 \pm 0,30$ & 0,91 \\
\hline
\end{tabular}


СІЛЬСЬКЕ ГОСПОДАРСТВО. ТВАРИННИЦТВО

3. Біологічні показники адаптації телиць до високих температур у пасовищний період

\begin{tabular}{|c|c|c|c|c|}
\hline \multirow{2}{*}{ Група } & \multicolumn{3}{|c|}{ Показник } & \multirow{2}{*}{ індекс } \\
\cline { 2 - 4 } & \multicolumn{3}{|c|}{ коефіцієнт } & теплостійкості \\
\cline { 2 - 4 } & адаптації & толерантності & термостійкості & 79,2 \\
\hline I & 2,156 & 86,2 & 2,031 & 71,2 \\
\hline II & 2,188 & 84,4 & 2,231 & 83,2 \\
\hline III & 2,070 & 89,8 & 2,010 & 81,2 \\
\hline IV & 2,106 & 88,0 & 2,020 & \\
\hline
\end{tabular}

За період вирощування, від народження і до парування, інтенсивно вирощені телиці III і IV груп мали середньодобовий приріст 780,0 і 731,0 г, що

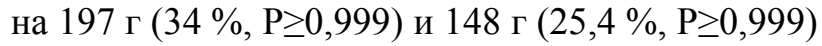
більше приростів аналогів контрольної групи.

Заплідненість від першого парування була вищою у тварин III і IV груп порівняно 3 контрольною (I) на $6 \%$ і 2,9\%. За кількістю осіменінь для запліднення телиці даних груп мали значно кращий показник. Так, кількість осіменінь для запліднення у телиць III i IV груп була меншою, відповідно, на $25 \%$ і $10 \%$ аналогів контрольної групи.

Жива маса на час отелення була також вищою в інтенсивно вирощених телиць на 23,3 кг (5\%, $\mathrm{P} \geq 0,95)$ i 4,6 кг (1\%).

Найважливішим інтер'єрним показником, безпосередньо пов'язаним 3 інтенсивністю окислювально-відновальних процесів та рівнем загального обміну речовин, а отже, з ростом і розвитком тварин, $\epsilon$ кров.

Залежно від сезону року змінюються і біохімічні показники крові. Дані, що характеризують білковий спектр сироватки крові телиць, наводяться в таблиці 2.

За кількістю білка і співвідношенням його фракцій як між тваринами різних груп, так і в різні сезони року, достовірних відмінностей не виявлено. Це свідчить про хорошу пристосованість телиць до різних господарських і кліматичних умов. Білковий коефіцієнт підвищився в зимовий період за рахунок відносного збільшення глобулінів у крові, що вказує на компенсацію захисної функції організму.

В інтенсивно вирощених телиць III і IV груп у 15-місячному віці в крові спостерігається тенденція до збільшення і перевищення кількості загального білка: в порівнянні з аналогами I групи ці відмінності були рівні 6,3 \% і 3,1 \%.

Вміст альбумінів у сироватці крові, так само як і загального білка, пов'язаний зі швидкістю росту (середньодобовими приростами). За більш високого рівня альбумінів у сироватці крові, як правило, був вищим і середньодобовий приріст.
Таким чином, характерною особливістю підростаючих телиць $\epsilon$ наявність позитивного зв'язку між швидкістю росту і змістом альбумінів у сироватці крові.

Важливе значення в життєдіяльності організму належить глобулінам сироватки крові. Будучи носіями антитіл, вони виконують захисну функцію. 3 наших даних видно, що 3 віком у тварин усіх груп відбувається збільшення рівня глобулінів у сироватці крові. Так, із 8- до 15місячного віку значення цього показника збільшувалися у телиць I групи на 5,7 г/л (15,9\%), II - на 5,2 (15,0 \%), III - на 6,5 (17,7 \%), IV - на 6,1 (16,9\%) відповідно.

Таким чином, біохімічний склад крові дослідних тварин характеризується різного роду змінами, обумовленими віком і сезоном року.

За суттєвих змін зовнішніх умов утримання худоби на перехідній зоні степу і лісостепу важливе значення має адаптаційна пластичність $i$, передусім, здатність переносити високу температуру влітку. Отримані нами дані свідчать про незначну міжгрупову різницю (табл. 3).

Відомо, що чим нижча абсолютна величина коефіцієнтів адаптації й термостійкості і вища коефіцієнта толерантності та індексу теплостійкості, тим вища у тварин стійкість до спеки. Як видно із даних таблиці 1 , коефіцієнт адаптації й термостійкості в усіх групах має показник два, що свідчить про добру термостійкість і високий ступінь витривалості телиць в умовах підвищених температур.

Тварини III i IV груп відрізнялися дещо кращими показниками коефіцієнтів адаптації і термостійкості; ці показники у них були нижчі на 0,086 і 0,05; 0,021 і 0,011 відповідно, порівняно 3 ровесницями I групи.

Високу толерантність мають телиці всіх дослідних груп. Наведені вище показники свідчать про те, що дослідні тварини ідеально пристосовані до підвищеної температури повітря.

Перевага індексу теплостійкості порівняно 3 коефіцієнтом толерантності полягає в тому, що за допомогою першого враховується індивідуа- 
льна мінливість температури тіла і вводиться поправка на температуру середовища під час проведення досліду.

За ступенем стійкості до високої температури (ITУ) дослідні тварини характеризуються високою стійкістю до підвищеної температури навколишнього середовища. Спостерігається певне перевищення за коефіцієнтом толерантності в інтенсивно вирощених тварин дослідних тварин III i IV груп на 3,6 і 1,8; індексу теплостійкості - на 4 і 2 (у порівнянні з аналогами І групи).

3 погляду терморегуляції суттєве значення має й інтенсивність вирощування. Так, судячи 3

\section{БІБЛІОГРАФІЯ}

1. Вишневський В. М. Господарсько-біологічні особливості різних генотипів м'ясної худоби в умовах Полісся України / Автореф. дис. ... канд. с.-х. наук. - К., 1997. - 17 с.

2. Вдовіченко Ю. В., Подрезко Г. В. Поліська м'ясна порода великої рогатої худоби // Аграрний вісник Причорномор'я. - Випуск 58. - Одеса, 2011. - C. 10-13.

3. Гончаренко Л. В., Ізвеков М. Е. Оптимальний біологічних показників, які були дещо кращими у тих тварин, які знаходилися в умовах високого й інтенсивно-помірного, ніж у тих, які перебували на нормованому і низькому вирощуванні.

Висновок. Нормалізація основних фізіологічних функцій і поліпшення відтворювальних якостей у тварин свідчать про пристосованість телиць знам'янського внутрішньопородного типу до умов літньої жари та про доцільність розведення цієї худоби в степовій зоні України. Для більш ефективної акліматизації важливе значення має забезпечення тварин біологічно повноцінним кормом.

вік першого плодотворного осіменіння телиць м'ясних порід // Проблеми зооінженерії та ветеринарної медицини: Збірник наукових праць / Харк. зоовет. ін-т. - Х., 1998. - Вип. 3 (27). C. $80-82$.

4. Костенко B. Технологія вирощування ремонтних телиць // Агробізнес сьогодні. - № 20 (243). 2012. - C. 20-23. 